Article

\title{
Trade-Offs between Economic and Environmental Optimization of the Forest Biomass Generation Supply Chain in Inner Mongolia, China
}

\author{
Min Zhang $\left.{ }^{1} \mathbb{C}^{(}\right)$, Guangyu Wang ${ }^{2}$, Yi Gao ${ }^{3}$, Zhenqi Wang ${ }^{1}$ and Feng Mi ${ }^{1, *}$ \\ 1 School of Economics and Management, Beijing Forestry University, 35 Qinghua East Rd, Haidian District, \\ Beijing 100083, China; 18810371336@163.com (M.Z.); wang_zhenqi@126.com (Z.W.) \\ 2 Department of Forest Resources Management, University of British Columbia, \\ Vancouver, BC V6T 1Z4, Canada; guangyu.wang@ubc.ca \\ 3 Department of Wood Science, University of British Columbia, Vancouver, BC V6T 1Z4, Canada; \\ evelyn.gaooo@gmail.com \\ * Correspondence: mifengsun@163.com
}

Received: 14 September 2017; Accepted: 27 October 2017; Published: 6 November 2017

\begin{abstract}
The utilization of forest residue to produce forest biomass energy can mitigate $\mathrm{CO}_{2}$ emissions and generate additional revenue for related eco-enterprises and farmers. In China, however, the benefit of this utilization is still in question because of high costs and $\mathrm{CO}_{2}$ emissions in the entire supply chain. In this paper, a multi-objective linear programming model (MLP) is employed to analyze the trade-offs between the economic and environmental benefits of all nodes within the forest biomass power generation supply chain. The MLP model is tested in the Mao Wu Su biomass Thermoelectric Company. The optimization results show that (1) the total cost and $\mathrm{CO}_{2}$ emissions are decreased by US\$98.4 thousand and 60.6 thousand $\mathrm{kg}$, respectively; 3750 thousand $\mathrm{kg}$ of waste-wood products is reduced and 3750 thousand $\mathrm{kg}$ of sandy shrub stubble residue is increased; (2) $64 \%$ of chipped sandy shrub residue is transported directly from the forestland to the power plant, $36 \%$ of non-chipped sandy shrub residue is transported from the forestland to the power plant via the chipping plant; (3) transportation and chipping play a significant role in the supply chain; and (4) the results of a sensitivity analysis show that the farmer's average transportation distance should be $84.13 \mathrm{~km}$ and unit chipping cost should be $\$ 0.01022$ thousand for the optimization supply cost and $\mathrm{CO}_{2}$ emissions. Finally, we suggest the following: (1) develop long-term cooperation with farmers; (2) buy chain-saws for regularly used farmers; (3) build several chipping plants in areas that are rich in sandy shrub.
\end{abstract}

Keywords: $\mathrm{CO}_{2}$ emissions; supply cost; sandy shrub stubble residue; wood-chipping residue; waste-wood products; residue-recycling; transportation path

\section{Introduction}

Strong dependence on fossil fuels such as coal, oil, and gas has caused energy shortage problems and massive greenhouse gas (GHG) emissions, which has exacerbated the conflicts between economic growth and environmental sustainability [1-3]. In China, the government has officially made the commitment that the carbon intensity per unit of gross domestic product (GDP) should be reduced by $40-45 \%$ by 2020 in relation to 2005 levels [4]; the government has also moved toward sustainability by minimizing the usage of non-renewable energy [5]. Therefore, it is necessary to search for alternative sources of renewable energy [1], including bioenergy and residue-resources to cope with energy shortage and $\mathrm{CO}_{2}$ emissions. China's biomass resources show great potential, producing the equivalent of 46 million tons of standard coal for energy use [6]. Specifically, forest biomass energy is a priority for energy development and target planning due to its high fuel value and low carbon 
output [7]. As such, forests are the most important source of biomass energy from the perspective of resource potential [8,9].

Forest biomass energy can be classified as traditional forest wood-fuel and modern forest biomass energy $[10,11]$. Traditional forest wood-fuel has been used for many years in rural areas, while modern forest biomass energy is generated by transforming forest wood resources into energy products including pellet fuel, biodiesel, bio-ethanol, forest biomass power generation and gas fuel. Forest biomass power generation in particular has gained attention in many developed countries and in the energy industry. There are now more than 300 power plants fueled by agricultural and forest biomass in European countries including Denmark, Finland, Sweden, and The Netherlands [12]. Developing countries and regions such as India, Brazil and Southeast Asia have also actively introduced technology to build biomass power generation projects. In China, the forest biomass power generation industry is growing rapidly, with about 254 projects involving agricultural and forest biomass power generation providing an annual electricity capacity of 29.85 billion $\mathrm{kWh}$ in 2016 [13]. The recent growth in this industry includes the establishment of Mao Wu Su biomass thermoelectric company in Inner Mongolia which is China's first sandy shrub biomass power plant and serves as the world's first demonstration project that uses sandy shrub stubble residue for direct combustion in semi-arid areas. This success story was featured by United Nations news in 2012 [14].

In Inner Mongolia, growth of the national sandy shrub can not only act as protection against wind and sand, but can also be directly burned as raw material for biomass power generation. In addition, the regular stubble tending of sandy shrub provides an important foundation for the enterprise. However, since sandy shrub is a low-density fuel resource that is scattered around a large geographic region [15], it is expensive to collect, chip, and transport. Moreover, the availability varies monthly and is dependent on traditional harvesting operations [16]. In order to prevent stock shortages, the company needs to store the raw material in advance, which leads to high storage costs. In general, low density, broad dispersion, uneven seasonal supply, and long chipping distances significantly increase the transportation and shortage costs of sandy shrub residue. On the other hand, compared to fossil fuels, sandy shrub residue is more environmentally friendly although the node of planting, harvesting, skidding, storage, transportation and chipping will involve non-renewable energy inputs and inevitably contribute to emissions [17]. In order to make profits and control $\mathrm{CO}_{2}$ emissions in the long-term, there is a need to develop a model for the Mao Wu Su biomass Thermoelectric Company to optimize their raw material supply chain and optimize its economic and ecological benefits.

Previous research has focused on impact assessment of developing a forest-biomass power generation industry [18,19], energy price forecasting [20,21] and industrial development policy [22-24] by local equilibrium models and system dynamics (SD) to study forest biomass energy supply and demand at the global or national scale. On the other hand, some scholars have used qualitative methods to study the pricing mechanism of renewable energy [25], industry policy [26] and existing problems $[27,28]$ in the country or from a small-scale point of view. With regard to the supply of raw materials for the industry, research is focused on the optimization of cost and $\mathrm{CO}_{2}$ emissions $[29,30]$ concerning the harvesting [31], transportation [32] and storing nodes [33] and the whole optimization of the forest biomass supply chain [34-36]. Particularly, there is also some research on the optimization of the wood biomass energy industry [37-40]. However, little research has included an in-depth study on forest biomass residue for residue-recycling, which has high bioenergy potential.

In this paper, a multi-objective linear programming model (MLP) is developed to analyze the trade-offs between the economic and environmental benefits of all nodes within the forest biomass power generation supply chain, including residues, and it is tested on the Mao Wu Su biomass Thermoelectric Company.

\section{Materials and Methods}

The Mao Wu Su biomass Thermoelectric Company is located in the Wu Shen banner of Ordos, Inner Mongolia Autonomous Region in China (Figure 1), which is rich with sandy shrub but suffers 
from harsh ecological conditions. It was registered in 2006 and formally entered into business in 2009 . It has perfectly combined forest biomass energy exploitation and desertification prevention. This provided a meaningful basis for an in-depth study on the supply chain in the forest biomass power generation industry.

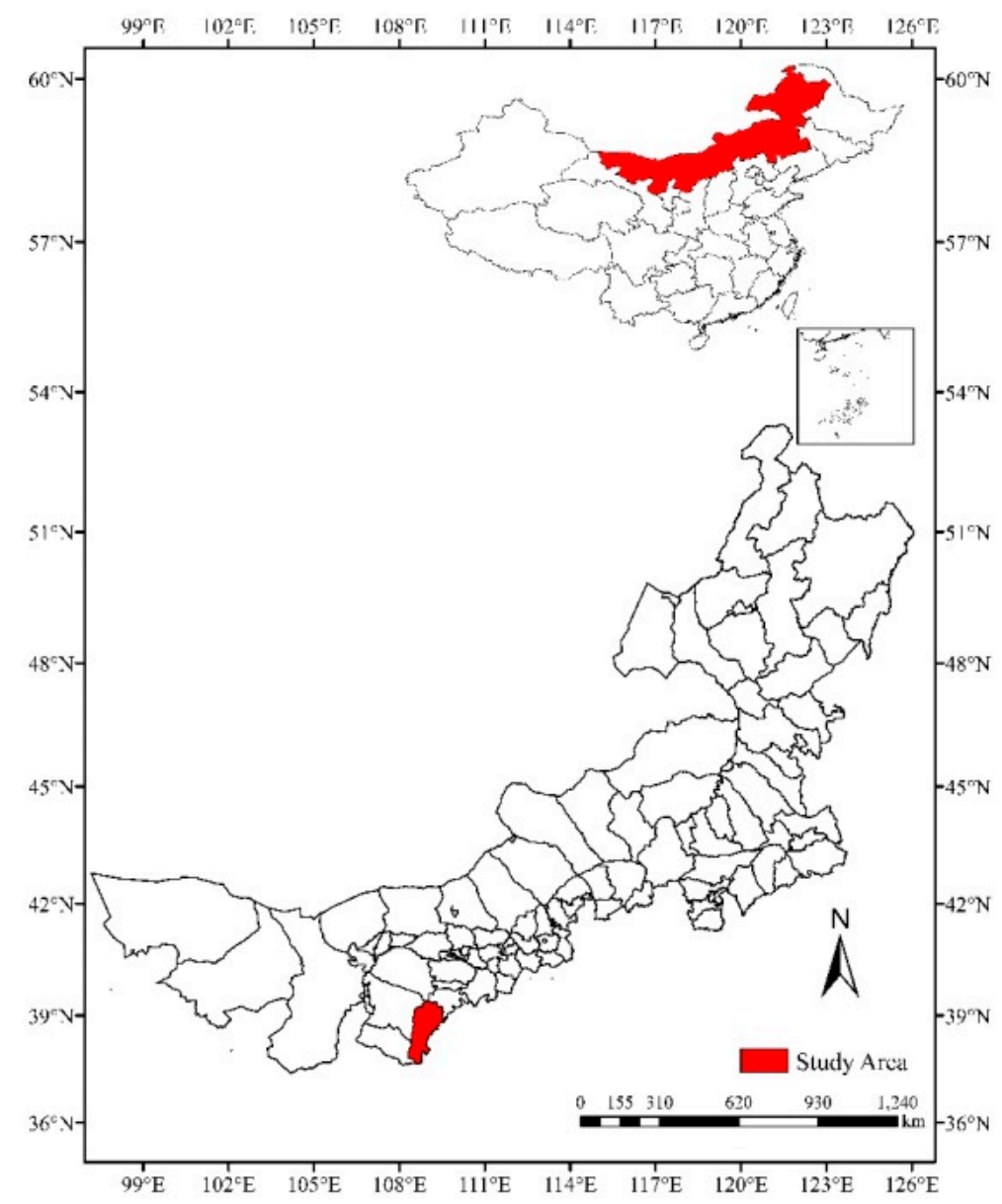

Figure 1. Study area. Wu Shen banner of Ordos, Inner Mongolia Autonomous Region in northern China.

Supply chain theory, the MLP method, and a sensitivity analysis are employed to conduct empirical research. The supply chain is seen as a network that consists of logistics, information and capital flow in order to effectively deliver the product to the consumer with the lowest cost. There are various MLP models currently used in practical work. The first method is to transform several goals into a relatively single target, such as the linear weighting method. The second method is the hierarchical sequence method. The third method is the analytic hierarchy process (AHP), which is suitable for the multi-objective analysis without necessary data and serves as a kind of qualitative and quantitative combination. A sensitivity analysis is used to explore the relationship between relevant factors and key indicators [41]. In this paper, the supply chain of the forest biomass industry concerns planting, harvesting, skidding, storage, chipping and transportation and optimizes the entire supply chain process with the goal of minimizing the total cost. The three key raw materials in this paper are sandy shrub stubble residue, wood-chipping residue and waste-wood products; the transportation path of three key raw materials is shown in Figure 2. The first MLP method is applied to optimize the trade-offs between the economic and environmental benefits by the Solver, including $\lambda_{c} \lambda_{e}$ which are the weight of cost and $\mathrm{CO}_{2}$ function, respectively. The sensitivity analysis is employed to explore the impact of the key parameters in transportation and chipping on the optimal supply chain solution. 


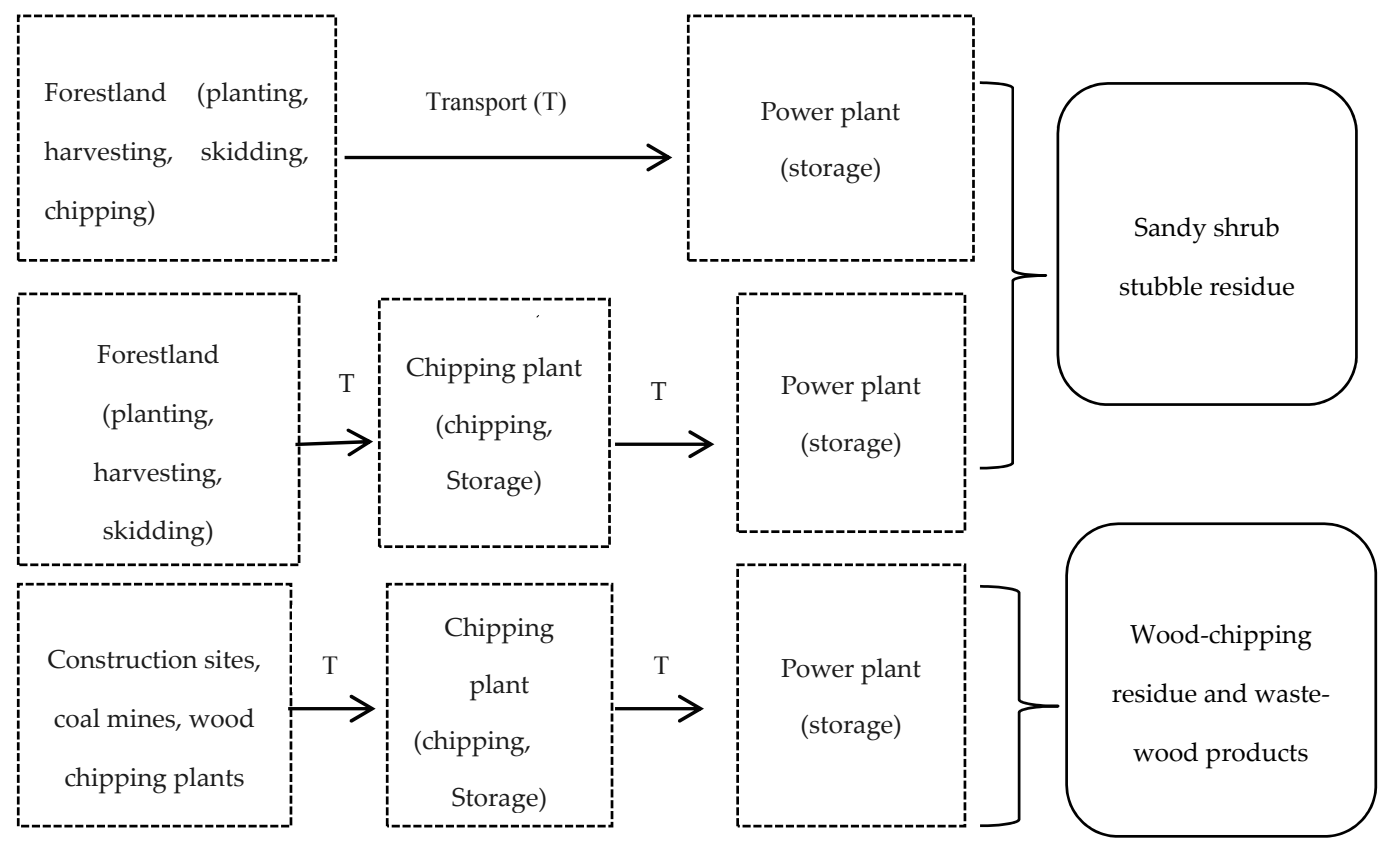

Figure 2. The transportation path of three kinds of raw materials in the biomass supply chain for the Mao Wu Su biomass Thermoelectric Company. Note: the transportation path is from the case study questionnaire.

\subsection{Model}

\subsubsection{Objective Function}

A multi-objective linear programming model was developed in Equation (1) with supply cost function (Equation (2)) and the $\mathrm{CO}_{2}$ emissions function (Equation (3)). The assumptions are described due to research limitations: the raw materials demand of the power plant is definite and the labor salary keeps steady; the cost and $\mathrm{CO}_{2}$ emissions of wood-chipping residue and waste-wood products for residue-recycling in planting, harvesting and skidding are zero.

$$
\begin{gathered}
\min (\varphi)=\lambda_{c} \times f_{c}+\lambda_{e} \times f_{e} \\
\min \left(f_{c}\right)=C^{\text {plant }}+C^{\text {harv }}+C^{\text {skid }}+C^{\text {stor }}+C^{\text {chip }}+C^{\text {trans }} \\
\min \left(f_{e}\right)=E^{\text {plant }}+E^{\text {harv }}+E^{\text {skid }}+E^{\text {trans }}+E^{\text {stor }}+E^{\text {chip }}
\end{gathered}
$$

Note that in Equation (1), $\lambda_{c}$ and $\lambda_{e}$ represent the weight of supply cost and $\mathrm{CO}_{2}$ emissions respectively; $f_{c}$ and $f_{e}$ represent the function value of supply cost and $\mathrm{CO}_{2}$ emissions respectively. In Equations (2) and (3), $C^{\text {plant }}, C^{\text {harv }}, C^{\text {skid }}, C^{\text {stor }}, C^{\text {chip }}$ and $C^{\text {trans }}$ indicate the supply cost in planting, harvesting, skidding, storage, chipping and transportation, in $\$ ; E^{\text {plant }}, E^{\text {harv }}, E^{\text {skid }}, E^{\text {trans }}, E^{\text {stor }}$ and $E^{\text {chip }}$ refer to the amount of $\mathrm{CO}_{2}$ emissions at each node of the supply chain, in $\mathrm{kg}$.

\subsubsection{Cost Functions}

The parameters which are the set themselves in the overall model are shown in Appendix A. The cost functions for each stage of the supply chain are as follows:

$$
\begin{gathered}
C^{\text {plant }}=\sum_{i \in M_{i}} A_{i} \times c p_{i} \\
c p_{i}=c p_{i 1}+c p_{i 2}+c p_{i 3}+c p_{i 4}
\end{gathered}
$$




$$
c p_{i 2}=\sum_{i \in M_{i}} l p_{i} \times P p_{i}
$$

where $M_{i}$ refers to the set of three key raw materials $i ; A_{i}$ represents the total planting area of materials, in ha; $c p_{i}$ is the unit planting cost which encompasses land costs $\left(c p_{i 1}\right)$, labor costs $\left(c p_{i 2}\right)$, equipment costs $\left(c p_{i 3}\right)$ and other material costs $\left(c p_{i 4}\right)$, in $\$ \cdot h a^{-1} ; l p_{i}$ is the amount of labor, in worker.h.ha ${ }^{-1}$; and $P p_{i}$ is the unit labor salary, in $\$ \cdot$ worker $^{-1} \cdot \mathrm{h}^{-1}$.

$$
\begin{gathered}
C^{h a r v}=\sum_{i \in M_{i}} B_{i} \times c h_{i} \\
c h_{i}=c h_{i 1}+c h_{i 2}+c h_{i 3} \\
c h_{i 1}=\sum_{i \in M_{i}} l h_{i} \times P h_{i}
\end{gathered}
$$

where $B_{i}$ represents the harvesting amount of raw materials, in $\mathrm{kg} ; \mathrm{ch}_{i}$ is the unit harvesting cost which contains labor costs $\left(c h_{i 1}\right)$, equipment costs $\left(c h_{i 2}\right)$ and other material costs $\left(c h_{i 3}\right)$, in $\$ \cdot \mathrm{kg}^{-1} ; l h_{i}$ is the amount of labor, in worker $\cdot h \cdot h a^{-1}$; and $P h_{i}$ is the unit labor salary, in $\$ \cdot$ worker $^{-1} \cdot \mathrm{h}^{-1}$.

$$
\begin{aligned}
C^{s k i d} & =\sum_{i \in M_{i}} \sum_{d \in D_{d}} c s k_{i d} \times D_{i d} \\
c s k_{i d} & =c s k_{i d 1}+c s k_{i d 2}+c s k_{i d 3} \\
c s k_{i d 1} & =\sum_{i \in M_{i}} \sum_{d \in D_{d}} l s k_{i d} \times P s k_{i d}
\end{aligned}
$$

where $D_{d}$ represents the set of skidding points $d ; D_{i d}$ represents the amount of skidding, in $\mathrm{kg}$; $c s k_{i d}$ is the unit skidding cost which consists of labor costs $\left(c s k_{i d 1}\right)$, equipment investment costs $\left(c s k_{i d 2}\right)$ and other material costs $\left(c s k_{i d 3}\right)$, in $\$ \cdot \mathrm{kg}^{-1}$; $l s k_{i d}$ is the amount of labor, in worker $\cdot \mathrm{h} \cdot \mathrm{kg}^{-1}$; and $P s k_{i d}$ is the unit labor salary, in $\$ \cdot$ worker $^{-1} \cdot \mathrm{h}^{-1}$.

$$
\begin{gathered}
C^{s t o r}=C^{s f i x}+C^{s v a r} \\
C^{s f i x}=\sum_{i \in M_{i}} \sum_{s \in D_{s}} c s t f_{i s} \\
C^{s v a r}=\sum_{i \in M_{i}} \sum_{s \in D_{s}} c s t v_{i s} \times N_{i s} \\
\operatorname{cstv}_{i s}=c_{s t v_{i s} 1}+c s t v_{i s} 2 \\
c_{s t v_{i s 1}}=\sum_{i \in M_{i}} \sum_{s \in D_{s}} l s t v_{i s} \times P_{s t v_{i s}}
\end{gathered}
$$

where $D_{s}$ represents the set of storage points $s ; C^{s f i x}$ is the fixed storage cost which includes land costs $\left(\operatorname{cst} f_{i s 1}\right)$ and construction costs $\left(\operatorname{cst} f_{i s 2}\right)$, in $\$ ; C^{s v a r}$ is the variable storage cost; $N_{i s}$ is the storage amount of raw materials, in $\mathrm{kg}$; $c s t v_{i s}$ is the unit variable storage costs which are related to labor costs $\left(c s t v_{i s 1}\right)$ and other material costs $\left(c s t v_{i s 2}\right)$, in $\$ \cdot \mathrm{kg}^{-1} ; l s t v_{i s}$ is the amount of labor, in worker $\cdot \mathrm{h} \cdot \mathrm{kg}^{-1}$; $P s t v_{i s}$ represents the unit labor salary, in $\$ \cdot$ worker $^{-1} \cdot \mathrm{h}^{-1}$.

$$
\begin{aligned}
C^{c h i p} & =\sum_{i \in M_{i}} \sum_{c \in D_{c}} c c_{i c} \times N_{i c} \\
c c_{i c} & =c c_{i c 1}+c c_{i c 2}+c c_{i c 3} \\
c c_{i c 1} & =\sum_{i \in M_{i}} \sum_{c \in D_{c}} l c_{i c} \times P c_{i c}
\end{aligned}
$$


where $D_{c}$ is the set of chipping points $c$; $N_{i c}$ is the amount of raw materials chipped in the chipping plant, in $\mathrm{kg} ; c c_{i c}$ is the unit chipping costs which include labor costs $\left(c c_{i c 1}\right)$, equipment investment $\left(c c_{i c 2}\right)$ and other material costs $\left(c c_{i c 3}\right)$, in $\$ \cdot \mathrm{kg}^{-1} . l c_{i c}$ represents the amount of labor, in worker $\cdot \mathrm{h} \cdot \mathrm{kg}^{-1}$; $P c_{i c}$ represents the unit labor salary, in $\$ \cdot$ worket $^{-1} \cdot \mathrm{h}^{-1}$.

$$
\begin{gathered}
C^{\text {trans }}=\sum_{i \in M_{i}} \sum_{j \in T_{j}} \sum_{k \in K_{k}} \sum_{y \in Y_{y}} c t_{i j k y 1} \times x_{i j k y} \times d_{j}+\sum_{i \in M_{i}} \sum_{j \in T_{j}} \sum_{k \in K_{k}} \sum_{y \in Y_{y}} c t_{i j k y 2} \times x_{i j k y} \\
c t_{i j k y 1}=\sum_{i \in M_{i}} \sum_{j \in T_{j}} \sum_{k \in K_{k}} \sum_{y \in Y_{y}}\left(l t_{i j k y 11} \times P t_{i j k y 11}+c t_{i j k y 12}\right) \\
c t_{i j k y 2}=\sum_{i \in M_{i}} \sum_{j \in T_{j}} \sum_{k \in K_{k}} \sum_{y \in Y_{y}} l t_{i j k y 21} \times P t_{i j k y 21}
\end{gathered}
$$

where $T_{j}$ represents the set of transportation paths $j ; K_{k}$ represents the form of the raw material $k ; Y_{y}$ is the transportation equipment $y ; d_{j}$ is the transportation distance of path $j$, in $\mathrm{km} ; x_{i j k y}$ is the quantity of raw materials, in kg; the first section of Equation (21) is the transportation costs and the second section of Equation (21) is the loading and unloading costs, in $\$ ; c t_{i j k y 1}$ is the unit transportation costs, in $\$ \cdot \mathrm{kg}^{-1} \cdot \mathrm{km}^{-1} ; l t_{i j k y 11}$ is the amount of labor involved in transportation, in worker $\cdot \mathrm{h} \cdot \mathrm{kg}^{-1} ; P t_{i j k y 11}$ is the labor salary in transportation, in $\$ \cdot$ worker ${ }^{-1} \cdot \mathrm{h}^{-1} ; c t_{i j k y 12}$ is the other material costs, in $\$ \cdot \mathrm{kg}^{-1} \cdot \mathrm{km}^{-1}$; $c t_{i j k y 2}$ is the unit loading and unloading costs, in $\$ \cdot \mathrm{kg}^{-1} ; l t_{i j k y 21}$ refers to the amount of labor involved in in loading and unloading, in worker $\cdot \mathrm{h}^{\mathrm{kg}}{ }^{-1} ; P t_{i j k y 21}$ is the labor salary in loading and unloading, in $\$ \cdot$ worker $^{-1} \cdot \mathrm{h}^{-1}$.

\subsubsection{Carbon Dioxide Emissions Functions}

$$
\begin{gathered}
E^{\text {plant }}=\sum_{i \in M_{i}}\left(e p_{i 1}+e p_{i 2}+e p_{i 3}\right) \\
e p_{i 1}=\sum_{i \in M_{i}} e p_{-} l_{i} \times A_{i} \\
e p_{i 2}=\sum_{i \in M_{i}} \sum_{u \in U_{u}} e p_{i u} \times T p_{i u} \\
e p_{i u}=\varepsilon_{u} \times \sum_{i \in M_{i}} \sum_{u \in U_{u}} N p_{i u} \\
e p_{i 3}=\sum_{i \in M_{i}} e l_{i} \times l p_{i} \times A_{i}
\end{gathered}
$$

where $U_{u}$ represents the set of planting equipment $u ; e p_{i 1}, e p_{i 2}$ and $e p_{i 3}$ represent the $\mathrm{CO}_{2}$ emissions from seedlings, machinery and labor, respectively, in $\mathrm{kg}$; $e p_{-} l_{i}$ is the $\mathrm{CO}_{2}$ emissions factor per unit area of land, in $\mathrm{kg} \cdot \mathrm{ha}^{-1} ; T p_{i u}$ represents the usage hour of equipment, in $\mathrm{h} ; e p_{i u}$ is the $\mathrm{CO}_{2}$ emissions factor of equipment, in $\mathrm{kg} \cdot \mathrm{h}^{-1} ; \varepsilon_{u}$ is the $\mathrm{CO}_{2}$ emissions coefficient of equipment, in $\mathrm{kg} \cdot \mathrm{L}^{-1} ; N p_{i u}$ is the energy consumption per hour, $\mathrm{L} \cdot \mathrm{h}^{-1} ; \mathrm{el}_{i}$ is the $\mathrm{CO}_{2}$ emissions factor of labor, in $\mathrm{kg} \cdot$ worker $^{-1} \cdot \mathrm{h}^{-1}$.

$$
\begin{gathered}
E^{h a r v}=\sum_{i \in M_{i}}\left(e h_{i 1}+e h_{i 2}\right) \\
e h_{i 1}=\sum_{i \in M_{i}} e l_{i} \times l h_{i} \times B_{i} \\
e p_{i 2}=\sum_{i \in M_{i}} \sum_{v \in V_{v}} e h_{i v} \times T h_{i v} \\
e h_{i v}=\varepsilon_{v} \times \sum_{i \in M_{i}} \sum_{v \in V_{v}} N h_{i v}
\end{gathered}
$$


where $V_{v}$ represents the set of harvesting equipment $v ; e h_{i 1}$ and $e h_{i 2}$ represent the $\mathrm{CO}_{2}$ emissions from labor and equipment, in $\mathrm{kg} ; e h_{i v}$ is the $\mathrm{CO}_{2}$ emissions factor of the equipment, in $\mathrm{kg} \cdot \mathrm{h}^{-1} ; \mathrm{Th}_{i v}$ represents the equipment operating time, in $\mathrm{h} ; \varepsilon_{v}$ is the $\mathrm{CO}_{2}$ emissions coefficient, in $\mathrm{kg} \cdot \mathrm{L}^{-1} ; N h_{i v}$ is the energy consumption per hour, in $\mathrm{L} \cdot \mathrm{h}^{-1}$;

$$
\begin{gathered}
E^{s k i d}=\sum_{i \in M_{i}}\left(e s k_{i 1}+e s k_{i 2}\right) \\
e s k_{i 1}=\sum_{i \in M_{i}} \sum_{d \in \mathrm{D}_{d}} e l_{i} \times l s k_{i d} \times D_{i d} \\
e s k_{i 2}=\sum_{i \in M_{i}} \sum_{w \in W_{w}} e s k_{i w} \times T s k_{i w} \\
e s k_{i w}=\varepsilon_{w} \times \sum_{i \in M_{i}} \sum_{w \in W_{w}} N s k_{i w}
\end{gathered}
$$

where $W_{w}$ is the set of skidding equipment $w ; e s k_{i 1}$ and $e s k_{i 2}$ are the $\mathrm{CO}_{2}$ emissions from labor and equipment, respectively, in $\mathrm{kg}$; esk $k_{i w}$ is the $\mathrm{CO}_{2}$ emissions factor of the equipment, in $\mathrm{kg} \cdot \mathrm{h}^{-1}$; $T s k_{i w}$ is the equipment operating time, in $\mathrm{h} ; \varepsilon_{w}$ is the the $\mathrm{CO}_{2}$ emissions coefficient of the equipment, in $\mathrm{kg} \cdot \mathrm{L}^{-1}$; $N s k_{i w}$ is the energy consumption per hour, in $\mathrm{L} \cdot \mathrm{h}^{-1}$.

$$
\begin{gathered}
E^{s t o r}=\sum_{i \in M_{i}} \sum_{s \in D_{s}}\left(e s t f_{i s}+e s t v_{i s}\right) \\
e s t f_{i s}=\sum_{i \in M_{i}} \sum_{s \in D_{s}}\left(e s t f_{i s 1} \times s s t f_{i s}+e s t f_{i s 2}\right) \\
e^{s t v_{i s}}=\sum_{i \in M_{i}} \sum_{x \in D_{s}}\left(e s t v_{i s 1} \times T_{s t v_{i s}}+\text { lstv }_{i s} \times N_{i s} \times e l_{i}\right) \\
\text { estv }_{i s 1}=\varepsilon_{s} \times \sum_{i \in M_{i}} \sum_{s \in D_{s}} N s t v_{i s}
\end{gathered}
$$

where $e s t f_{i s}$ is fixed $\mathrm{CO}_{2}$ emissions, in $\mathrm{kg}$; $e s t v_{i s}$ is variable $\mathrm{CO}_{2}$ emissions, in kg; est $f_{i s 1}$ is the land emissions factor, in $\mathrm{kg} \cdot \mathrm{ha}^{-1}$; $s s t f_{\text {is }}$ is the land area, in ha; $e s t f_{\text {is } 2}$ is the amount of $\mathrm{CO}_{2}$ emissions in construction, in $\mathrm{kg}$; estv is $1_{1}$ is the $\mathrm{CO}_{2}$ emissions factor of the site, in $\mathrm{kg} \cdot \mathrm{h}^{-1}$; $T s t v_{i s}$ is the operating hour of sites, in $\mathrm{h} ; \varepsilon_{s}$ is the $\mathrm{CO}_{2}$ emissions coefficient of the site, in $\mathrm{kg} \cdot \mathrm{L}^{-1} ; \mathrm{Nstv}_{i s}$ is the energy consumption per hour, in $\mathrm{L} \cdot \mathrm{h}^{-1}$.

$$
\begin{aligned}
E^{c h i p} & =\sum_{i \in M_{i}} \sum_{c \in D_{c}}\left(e c_{i c 1}+e c_{i c 2}\right) \\
e c_{i c 1} & =\sum_{i \in M_{i}} \sum_{c \in D_{c}} \sum_{x \in X_{x}} e c_{i c x} \times T c_{i c} \\
e c_{i c x} & =\varepsilon_{x} \times \sum_{i \in M_{i}} \sum_{c \in D_{c}} \sum_{x \in X_{x}} N c_{i c x} \\
e c_{i c 2} & =\sum_{i \in M_{i}} \sum_{c \in D_{c}} l c_{i c} \times N_{i c} \times e l_{i}
\end{aligned}
$$

where $e c_{i c 1}$ and $e c_{i c 2}$ are the $\mathrm{CO}_{2}$ emissions of the equipment and the labor, respectively, in $\mathrm{kg} ; e c_{i c x}$ is the $\mathrm{CO}_{2}$ emissions factor of the equipment, in $\mathrm{kg} \cdot \mathrm{h}^{-1} ; T c_{i c}$ is the equipment operating time, in $\mathrm{h} ; \varepsilon_{x}$ is the $\mathrm{CO}_{2}$ emissions coefficient, in $\mathrm{kg} \cdot \mathrm{L}^{-1} ; N c_{i c x}$ is energy consumption per hour, in $\mathrm{L} \cdot \mathrm{h}^{-1}$.

$$
\begin{aligned}
E^{\text {trans }} & =\sum_{i \in M_{i}} \sum_{j \in T_{j}} \sum_{k \in K_{k}} \sum_{y \in Y_{y}}\left(e t_{i j k y 1}+e t_{i j k y 2}\right) \\
e t_{i j k y 1} & =\sum_{i \in M_{i}} \sum_{j \in T_{j}} \sum_{k \in K_{k}} \sum_{y \in Y_{y}} e t_{y} \times x_{i j k y} \times d_{j}
\end{aligned}
$$




$$
\begin{gathered}
e t_{y}=\varepsilon_{y} \times \sum_{y \in Y_{y}} N t_{y} \\
e t_{i j k y 2}=\sum_{i \in M_{i}} \sum_{j \in T_{j}} \sum_{k \in K_{k}} \sum_{y \in Y_{y}} e l_{i} \times\left(l t_{i j k y 11}+l t_{i j k y 21}\right)
\end{gathered}
$$

where $e t_{i j k y 1}$ and $e t_{i j k y 2}$ are the $\mathrm{CO}_{2}$ emissions of vehicles and labor, respectively, in $\mathrm{kg}$; $e t_{y}$ is the $\mathrm{CO}_{2}$ emissions factor of equipment $\mathrm{y}$, in $\mathrm{kg} \cdot \mathrm{kg}^{-1} \cdot \mathrm{km}^{-1} ; \varepsilon_{y}$ is the $\mathrm{CO}_{2}$ emissions coefficient, in $\mathrm{kg} \cdot \mathrm{L}^{-1} ; \mathrm{Nt}$ is energy consumption per hour, in $\mathrm{L} \cdot \mathrm{kg}^{-1} \cdot \mathrm{km}^{-1}$.

\subsubsection{Constraints}

The biomass power generation industry is a resource-constrained industry and there is a need for a certain amount of biomass resources to maintain the normal operation of the enterprise. Therefore, the supply chain optimization is constrained by the amount of resources. It restricts the total amount of raw materials that can be procured from the region in Equation (49); the total amount of skidding biomass is equal to the amount of harvesting biomass in Equation (50); the total amount of skidding biomass is equal to the amount of harvesting biomass in Equation (51); the amount of raw materials in chipping should not be more than the amount in storage which should not be greater than the total amount of raw materials in harvesting in Equation (52).

$$
\begin{gathered}
\sum_{i \in M_{i}} B_{i} \leq Z_{0} \\
\sum_{i \in M_{i}} \sum_{d \in D_{d}} D_{i d}=\sum_{i \in M_{i}} B_{i} \\
\sum_{i \in M_{i}} A_{i} \geq \sum_{i \in M_{i}} \frac{B_{i}}{B I_{i}} \\
\sum_{i \in M_{i}} B_{i} \geq \sum_{i \in M_{i}} \sum_{s \in D_{s}} N_{i s} \geq \sum_{i \in M_{i}} \sum_{c \in D_{c}} N_{i c}
\end{gathered}
$$

where $Z_{0}$ is the total resources in this region, in $\mathrm{kg} ; B I_{i}$ is the collection of raw material $i$ in unit area, in $\mathrm{kg} \cdot \mathrm{ha}^{-1}$.

Forest biomass resources are uneven in seasonal supply. The optimization is subject to the supply and demand. Equation (53) ensures that the total amount of raw materials must satisfy the requirement of the total demand; the total supply cost of raw material is limited to the purchase price paid by the power plant in Equation (54):

$$
\begin{gathered}
\sum_{i \in M_{i}} \sum_{j \in T_{j}} \sum_{k \in K_{k}} x_{i j k} \geq D_{0} \\
f_{c} \leq P_{0}
\end{gathered}
$$

where $D_{0}$ is the raw material demand, in $\mathrm{kg}$.

The optimization of the supply chain is limited by the radius of raw material collection. The longest transport path must be in the radius of the plant's raw material collection in Equation (55)

$$
\max _{j \in T_{j}} d_{j} \leq R_{0}
$$

where $R_{0}$ is the collecting radius, in $\mathrm{km}$.

\subsection{Data Source}

Data was gathered from two channels: statistical data collection and field investigation. The former was obtained from China Statistical Yearbook 2016 [42], China Energy Statistical Yearbook 2014 [43] and the Inner Mongolia Autonomous Region Forestry Department website [44]. The latter is 
first-hand data derived from interviews and questionnaires conducted among forest biomass power generation enterprises, middlemen, and farmers in the Inner Mongolia Autonomous Region. For the company, the average purchase price of sandy shrub stubble residue, wood-chipping residue and waste-wood products in 2015 was $\$ 58.64, \$ 54.13$ and $\$ 57.14$ per thousand $\mathrm{kg}$, respectively. The detailed parameters in each node of this company are presented as follows.

In planting, the $\mathrm{CO}_{2}$ emissions of the same kind of raw material are similar and there is no use of machinery equipment, only manual labor. The average need for planting per ha of Salix is 2.098 workers and the ratio between the households and the workers is 1:0.788. The average daily wage is $\$ 2.23$ per worker per hour. The cost of other materials (mainly pesticides) is $\$ 7.54$ per ha.

In harvesting, the equipment conditions and personnel operation level have no impact on $\mathrm{CO}_{2}$ emissions; there is no limit on the number of harvesting tools with the same power, fuel type and efficiency. The average unit labor input in harvesting is 1.347 workers per hour per thousand $\mathrm{kg}$ and the average harvest per ha is $7845 \mathrm{~kg}$. There are two types of machinery used in harvesting. Small hand-held harvesters $(v=1)$ incur a purchase cost of $\$ 178.61$, a life span of 3 years and average yearly maintenance costs of $\$ 29.76$, and the fuel is gasoline with a consumption of $2.5 \times 10^{-3} \mathrm{~L}$ per kg of raw materials. A medium-sized harvester $(v=2)$ has a purchase cost of $\$ 416.77$, a service life of 5 years, average yearly maintenance costs of $\$ 178.61$ and the fuel is diesel, with consumption of $3.5 \times 10^{-3} \mathrm{~L}$ on average per $\mathrm{kg}$ of raw materials. Characteristics of different energy sources are provided in Table 1.

Table 1. Reference factors of different energy sources [38].

\begin{tabular}{|c|c|c|c|c|}
\hline \multirow{2}{*}{ Energy } & Unit Price & Density & \multirow{2}{*}{$\begin{array}{l}\text { Average Low Calorific Value } \\
\left(\mathbf{k J} \cdot \mathrm{kg}^{-1}\right)\end{array}$} & \multirow{2}{*}{$\begin{array}{c}\text { Carbon Emissions Coefficient } \\
\left(\mathrm{kg} \cdot \mathrm{L}^{-1}\right)\end{array}$} \\
\hline & $\left(\$ \cdot L^{-1}\right)$ & $\left(\mathrm{kg} \cdot \mathrm{L}^{-1}\right)$ & & \\
\hline Gasoline & 6.41 & 0.728 & 43,070 & 2.925 \\
\hline Diesel & 5.94 & 0.84 & 42,652 & 3.095 \\
\hline
\end{tabular}

In skidding, storage and chipping, the point can be set numbers and have the greatest capacity limit; there is no limit on the number of skidding tools with the same power, fuel type and efficiency. The input in skidding is closely related to harvesting, chipping and transportation, so the parameters used in the model are merged into these nodes.

The daily storage in the company is up to 4500 thousand $\mathrm{kg}$ with 6.66 ha of open space. Assuming that the power plant operates for $24 \mathrm{~h}$, it is estimated that the storage needs two workers per day with an average of $\$ 5.36$ thousand per worker every year. There are no additional costs in the plant. The $\mathrm{CO}_{2}$ emissions merely originate from the workers' activity.

The chipping site of raw material for the company consists of two types: forestland chipping $(x=1)$ and chipping plant $(x=2)$. The chipping equipment parameters are involved in the forestland and chipping plant shown in Table 2 . There is an assumption that the only difference between each chipping plant is distance to the power plant.

In transportation, there is no limit on the number of transportation vehicles; and the speed, fuel and maximum load of each type of vehicle are similar; all kinds of transportation run at a constant speed and the road conditions and weather have no effect on $\mathrm{CO}_{2}$ emissions; all raw materials are under the same transportation conditions and a vehicle can be filled with all materials at the same time. The sandy shrub stubble residue can be acquired in two transportation ways: directly from the forestland to the power plant $(j=1)$ and from the forestland to the power plant via the chipping plant (middleman) $(j=2)$, while wood-chipping residue and waste-wood products are mainly from the chipping plant (middleman) to the power plant $(j=3)$. 
Table 2. The parameters of chipping equipment involved in the forestland and chipping plant.

\begin{tabular}{cccc}
\hline Equipment Parameters & Forestland & Chipping Plant & Unit \\
\hline Purchase cost & 2.75 & $29.77^{\mathrm{a}}$ & thousand \$ \\
Service life & 8 & 5 & year \\
Annual maintenance costs & 0.37 & 0.74 & thousand $\$$ \\
Power & $53 \times 10^{3}$ & $120 \times 10^{3}$ & $\mathrm{~W}$ \\
Energy consumption per $\mathrm{h}$ & 1.47 & 2.41 & $\mathrm{~L}$ \\
Carbon emissions factor & 3.82 & 7.91 & $\mathrm{~kg} \cdot \mathrm{h}^{-1}$ \\
Labor input per day & 1.50 & 15 & $\mathrm{worker}$ \\
Labor price per day & 0.02 & 0.01 & thousand $\$$ \\
Amount of raw materials processed per h & 0.63 & 25 & thousand kg \\
\hline Note: ${ }^{\text {a }}$ Equipment includes transformers, conveyor belts and chippers; the data is from the case study questionnaire.
\end{tabular}

The radius of the company is $200 \mathrm{~km}$, covering six towns including $\mathrm{Wu}$ Shen Zhao town, Ga Lu To town, Wu Ding He town, Tooke town, Ulan Tau Err town, and Su Zhen Lied. Transportation includes two types of vehicles: agricultural tricycles $(y=1)$ and trucks $(y=2)$. Agricultural tricycles are used for transporting sandy shrub stubble residue from the forestland to the chipping plant and trucks are often used to directly transport residue to power plants; waste-wood and wood-chipping residue is usually transported to the power plant by truck. The transport parameters of the vehicles are shown in Table 3.

Table 3. Parameters in transportation.

\begin{tabular}{cc}
\hline Parameters & Value \\
\hline Maximum unit load of agricultural tricycle & $1.5 \times 10^{3} \mathrm{~kg}$ \\
Agricultural tricycle fuel consumption $100 \mathrm{~km}$ & $8 \mathrm{~L}$ \\
Carbon emissions factor of agricultural tricycle & $0.171 \mathrm{~kg} \cdot \mathrm{km}^{-1}$ \\
Maximum unit load of truck & $10 \times 10^{3} \mathrm{~kg}$ \\
Trucks fuel consumption of $100 \mathrm{~km}$ & $38.5 \mathrm{~L}$ \\
Carbon emissions factor of truck & $0.481 \mathrm{~kg} \cdot \mathrm{km}^{-1}$ \\
\hline Note: the data is from the case study questionnaire.
\end{tabular}

\section{Results}

The supply cost and the amount of $\mathrm{CO}_{2}$ emissions in each node were optimized simultaneously by Solver for trade-offs between the economic and environmental benefits in the supply chain of forest biomass generation.

As shown in Table 4, the optimal results are as follows: the total amount of sandy shrub stubble residue, wood-chipping residue and waste-wood products is 93,750 thousand $\mathrm{kg}, 40,000$ thousand $\mathrm{kg}$ and 46,250 thousand $\mathrm{kg}$. Compared to the current supply, the power plant can achieve maximum economic and environmental benefits when 3750 thousand $\mathrm{kg}$ of waste-wood products is reduced, 3750 thousand $\mathrm{kg}$ of sandy shrub stubble residue is increased and the wood-chipping residue maintains the same supply as the current situation. Meanwhile, $64 \%$ of chipped sandy stubble residue should be directly transported to the power plant from the forestland, and $36 \%$ of non-chipped sandy stubble residue should be transported from the forestland to the power plant via the chipping plant.

The differences between the total supply cost of each node and three key raw materials in the current situation and the optimization are shown in Table 5. The total cost of the supply chain is $\$ 7451$ thousand after optimization which is decreased by $\$ 98.4$ thousand compared to the current condition. For each node, the total cost is reduced by different amounts; particularly, the total cost in the transportation node and chipping node is largely decreased with a reduction of $\$ 36.2$ thousand and $\$ 35.4$ thousand, respectively. For the three key raw materials, the total supply cost and the unit supply cost per thousand $\mathrm{kg}$ of the sandy shrub stubble residue (chipped in forestland) are optimized simultaneously; the total supply cost and the unit supply cost per thousand $\mathrm{kg}$ of sandy shrub stubble 
residue (chipped in the chipping plant) increase by exactly $\$ 195.8$ thousand and $\$ 0.0009$ thousand; the unit supply cost per thousand $\mathrm{kg}$ of the sandy shrub stubble residue (chipped in the chipping plant) is $\$ 0.049$ thousand which is larger than that of sandy shrub stubble residue (chipped in the forestland) after optimization; the total supply cost and the unit cost of wood-chipping residue keep steady; the total supply cost of waste-wood products is optimized but the unit supply cost per thousand $\mathrm{kg}$ increased by $\$ 0.0002$ thousand.

Table 4. The differences between the supply amount of three key raw materials in two situations (current supply amount and optimization supply amount) (Unit: thousand kg).

\begin{tabular}{cccc}
\hline Three Key Raw Materials & Current Supply Amount & Optimization Supply Amount & Differences \\
\hline Sandy shrub stubble residue & 90,000 & 93,750 & 3750 \\
Wood-chipping residue & 40,000 & 40,000 & 0 \\
Waste-wood products & 50,000 & 46,250 & -3750 \\
Total & 180,000 & 180,000 & 0 \\
\hline
\end{tabular}

Note: the data is from the case study questionnaire.

Table 5. The differences between the total supply cost of each node and three key raw materials under the current situation and optimization (Unit: thousand \$).

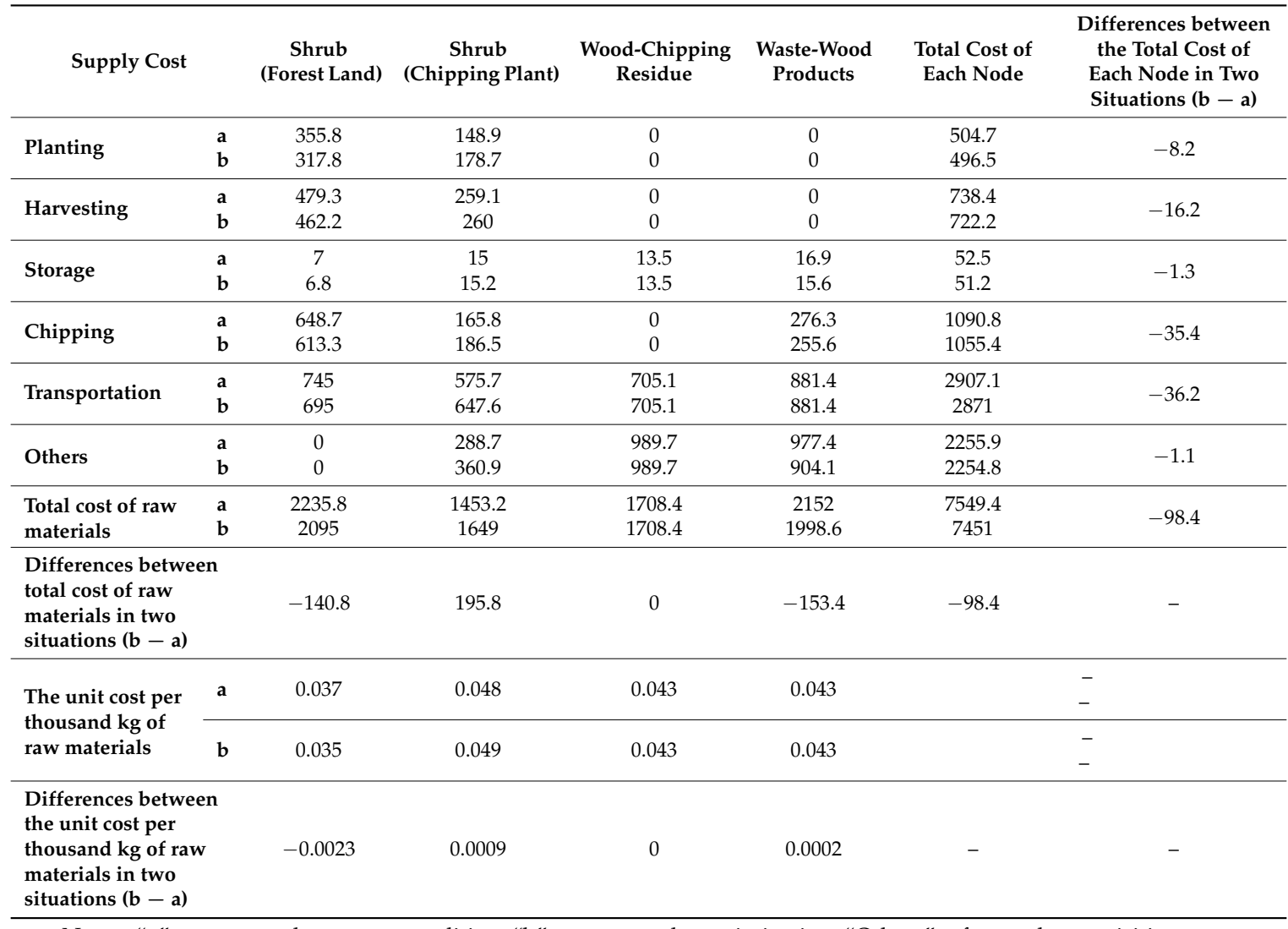

Notes: "a" represents the current condition; " $b$ " represents the optimization; "Others" refers to the acquisition costs of mainly waste-wood products and wood-chipping residue; the data is from the case study questionnaire.

The optimal supply cost percentages of each node and three key raw materials are presented in Figure 3a,b. In Figure 3a, the transportation cost accounts for $38.53 \%$ of the total cost, which represents a significant portion; the percentage of others is $30.26 \%$; the third largest is the cost of chipping, accounting for $14.17 \%$. In Figure $3 \mathrm{~b}$, the largest percentage of sandy shrub stubble residue (chipped in the forestland) is $28.1 \%$ and the smallest percentage of sandy shrub stubble residue (chipped in the chipping plant) is $22.2 \%$. 


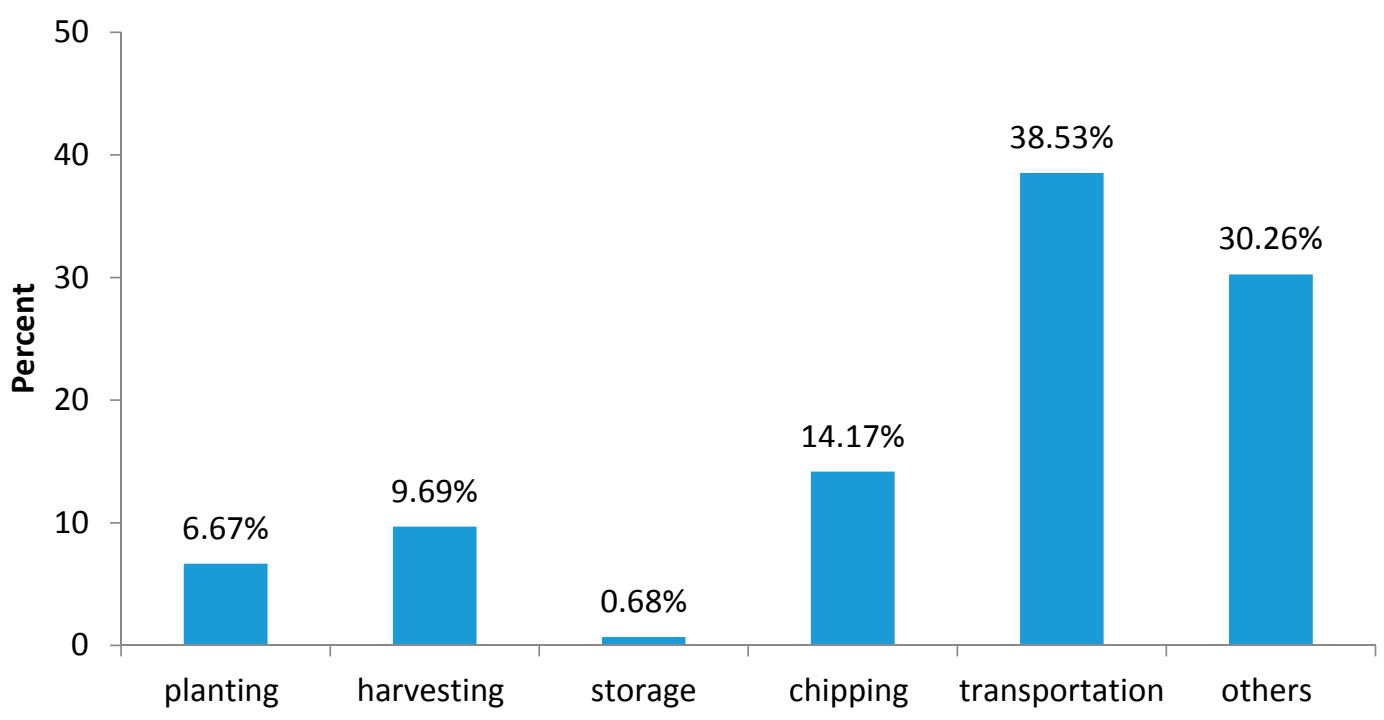

(a)

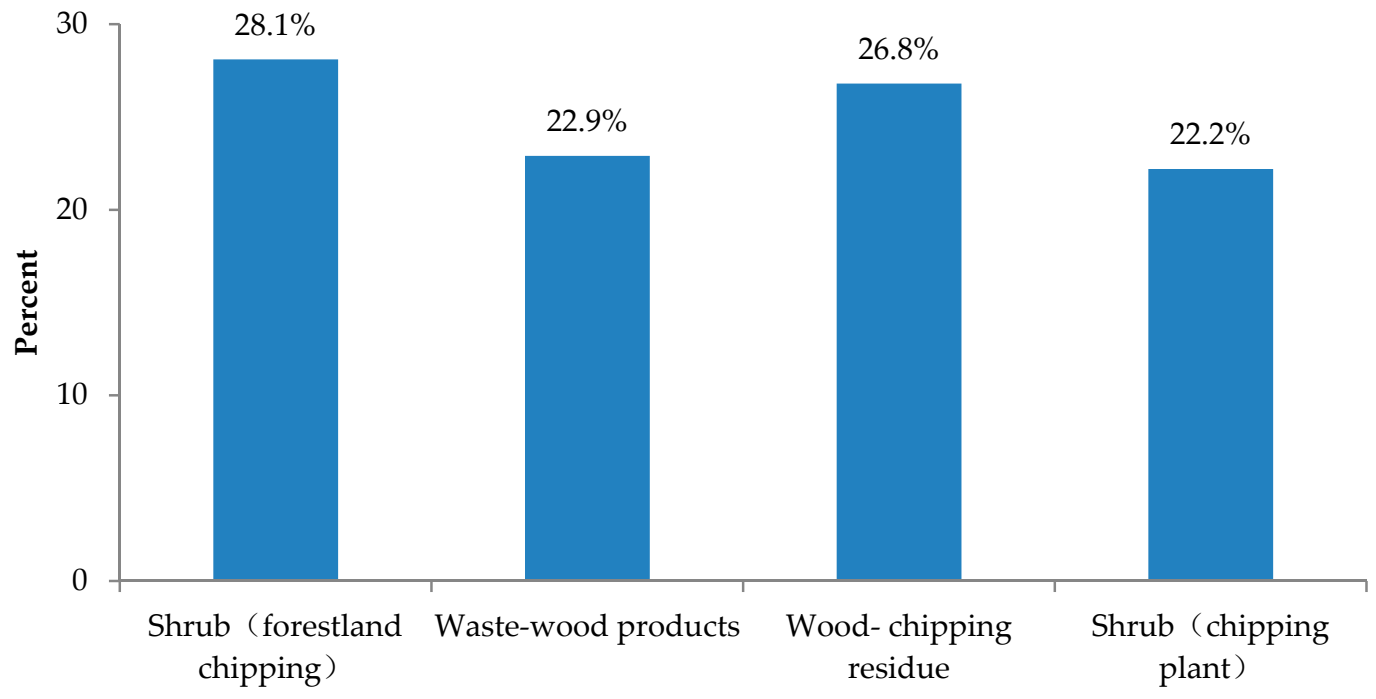

(b)

Figure 3. Percentage of the optimal supply cost of each node (a) and three key raw materials (b).

The differences between the total $\mathrm{CO}_{2}$ emissions of each node and three key raw materials under the current situation and the optimization are shown in Table 6. The total $\mathrm{CO}_{2}$ emissions of the supply chain are 5683.8 thousand $\mathrm{kg}$ which is decreased by 60.6 thousand $\mathrm{kg}$ compared to the current condition. For each node, the total $\mathrm{CO}_{2}$ emissions are reduced by different amounts; the total $\mathrm{CO}_{2}$ emissions in transportation and chipping nodes are largely decreased with a reduction of 44.8 thousand $\mathrm{kg}$ and 24.9 thousand $\mathrm{kg}$. As for the three key raw materials, the overall $\mathrm{CO}_{2}$ emissions and the unit $\mathrm{CO}_{2}$ emissions of sandy shrub stubble residue (chipped in the chipping plant) are optimized at the same time, but the overall $\mathrm{CO}_{2}$ emissions and the unit $\mathrm{CO}_{2}$ emissions per thousand $\mathrm{kg}$ of the sandy shrub stubble residue (chipped in the forestland) increase by exactly 10 thousand $\mathrm{kg}$ and 0.0002 thousand $\mathrm{kg}$, respectively; the unit $\mathrm{CO}_{2}$ emissions per thousand $\mathrm{kg}$ of the sandy shrub stubble residue (chipped in forestland) are 0.0317 thousand $\mathrm{kg}$ which is larger than that of sandy shrub stubble residue (chipped in the chipping plant) after optimization; the overall $\mathrm{CO}_{2}$ emissions and the unit $\mathrm{CO}_{2}$ emissions per thousand $\mathrm{kg}$ of wood-chipping residue keep steady; the $\mathrm{CO}_{2}$ emissions of waste-wood products are optimized but the unit $\mathrm{CO}_{2}$ emissions per thousand $\mathrm{kg}$ increased by 0.0014 thousand $\mathrm{kg}$. 
Table 6. The differences between total $\mathrm{CO}_{2}$ emissions of each node and three key raw materials under the current situation and optimization (Unit: thousand $\mathrm{kg}$ ).

\begin{tabular}{|c|c|c|c|c|c|c|c|}
\hline $\mathrm{CO}_{2}$ Emissions & & $\begin{array}{l}\text { Shrub } \\
\text { (Forest Land) }\end{array}$ & $\begin{array}{c}\text { Shrub } \\
\text { (Chipping Plant) }\end{array}$ & $\begin{array}{l}\text { Wood-Chipping } \\
\text { Residue }\end{array}$ & $\begin{array}{l}\text { Waste-Wood } \\
\text { Products }\end{array}$ & $\begin{array}{l}\text { Total Emissions } \\
\text { of Each Node }\end{array}$ & $\begin{array}{c}\text { Differences between } \\
\text { Total Emissions of } \\
\text { Each Node in Two } \\
\text { Situations }(b-a)\end{array}$ \\
\hline \multirow[t]{2}{*}{ Planting } & a & 195.1 & 109.8 & 0 & 0 & 304.9 & \multirow{2}{*}{-0.1} \\
\hline & b & & 109.7 & 0 & 0 & & \\
\hline \multirow{2}{*}{ Harvesting } & $\mathbf{a}$ & 594.6 & 207.8 & 0 & 0 & 802.4 & \multirow[b]{2}{*}{-0.7} \\
\hline & $\mathbf{b}$ & 594.5 & 207.2 & 0 & 0 & 801.8 & \\
\hline \multirow{2}{*}{ Storage } & $\mathbf{a}$ & 0.002 & 0.000 & 0.001 & 0.001 & 0.0 & \multirow{2}{*}{0.0} \\
\hline & $\mathbf{b}$ & 0.002 & 0.005 & 0.005 & 0.001 & 0.0 & \\
\hline \multirow{2}{*}{ Chipping } & $\mathbf{a}$ & 410.6 & 313.9 & 0 & 465 & 1189.5 & \multirow{2}{*}{-24.9} \\
\hline & b & 420.6 & 313.9 & 0 & 430.1 & 1164.6 & \\
\hline \multirow{2}{*}{ Transportation } & $\mathbf{a}$ & 689.5 & 392.8 & 1075.2 & 1300 & 3457.5 & \multirow{2}{*}{-44.8} \\
\hline & $\mathbf{b}$ & 689.7 & 382.4 & 1075.2 & 1265.4 & 3412.7 & \\
\hline \multirow{2}{*}{$\begin{array}{l}\text { Total emissions of } \\
\text { raw materials }\end{array}$} & $\mathbf{a}$ & 1889.8 & 1014.3 & 1075.2 & 1765.0 & 5744.4 & \multirow{2}{*}{-60.6} \\
\hline & $\mathbf{b}$ & 1899.8 & 1013.3 & 1075.2 & 1695.5 & 5683.8 & \\
\hline $\begin{array}{l}\text { Differences between } \\
\text { total emissions of } \\
\text { materials in two } \\
\text { situations }(b-a)\end{array}$ & & 10.0 & -1.1 & 0 & -69.5 & -60.6 & - \\
\hline \multirow{2}{*}{$\begin{array}{l}\text { The unit emissions } \\
\text { per thousand } \mathrm{kg} \text { of } \\
\text { raw materials }\end{array}$} & $\mathbf{a}$ & 0.0315 & 0.0338 & 0.0269 & 0.0353 & & \multirow{2}{*}{$\begin{array}{l}- \\
- \\
-\end{array}$} \\
\hline & $\mathbf{b}$ & 0.0317 & 0.0300 & 0.0269 & 0.0367 & & \\
\hline \multicolumn{2}{|l|}{$\begin{array}{l}\text { Differences between } \\
\text { the unit emissions per } \\
\text { thousand } \mathrm{kg} \text { of raw } \\
\text { materials in two } \\
\text { situations }(\mathrm{b}-\mathrm{a})\end{array}$} & 0.0002 & -0.0038 & 0 & 0.0014 & - & - \\
\hline
\end{tabular}

The percentage of optimal $\mathrm{CO}_{2}$ emissions for each node and three key raw materials is presented in Figure $4 a, b$. In Figure 4a, transportation accounts for $60.04 \%$ of $\mathrm{CO}_{2}$ emissions, which is a significant portion; chipping accounts for $20.49 \%$ of $\mathrm{CO}_{2}$ emissions; the third largest is the $\mathrm{CO}_{2}$ emissions of harvesting, accounting for $14.10 \%$. In Figure $4 \mathrm{~b}$, the largest percentage of sandy shrub stubble residue (chipped in the forestland) accounts for 33\% of $\mathrm{CO}_{2}$ emissions and the smallest percentage of sandy shrub stubble residue (chipped in the chipping plant) accounts for $18 \%$ of $\mathrm{CO}_{2}$ emissions.

Transportation and chipping have the greatest overall impact in the supply chain. We therefore selected these as critical nodes for the sensitivity analysis. In transportation, differentiation for the path of sandy shrub residue can be reflected by the farmer's average transportation distance. The parameter of transportation distance is $119.71 \mathrm{~km}$ in the optimal model. When the optimal supply of three key raw materials remains unchangeable, the transportation distance varies by $\pm 30 \%$. The results of the sensitivity analysis on transportation distance show that (1) when the transportation distance decreased by $30 \%$, the supply cost and the $\mathrm{CO}_{2}$ emissions are $\$ 7333.7$ thousand and 5356.9 thousand $\mathrm{kg}$, respectively; (2) when the transportation distance increased by $30 \%$, the supply cost and the $\mathrm{CO}_{2}$ emissions are $\$ 7569.2$ thousand and 6304.7 thousand $\mathrm{kg}$, respectively (Table 7).

In chipping, the unit chipping costs have a significant impact in the supply chain. When the optimal supply of three key raw materials remains unchangeable, the transportation distance varies by $\pm 14.7 \%$. The results of the sensitivity analysis show that (1) when the unit chipping cost decreases by $14.7 \%$, the supply cost and the $\mathrm{CO}_{2}$ emissions are $\$ 7180.7$ thousand and 5729.2 thousand $\mathrm{kg}$, respectively; (2) when the unit chipping cost increases by $14.7 \%$, the supply cost and the $\mathrm{CO}_{2}$ emissions are $\$ 7721.2$ thousand and $5698.2 \mathrm{~kg}$, respectively (Table 8). 


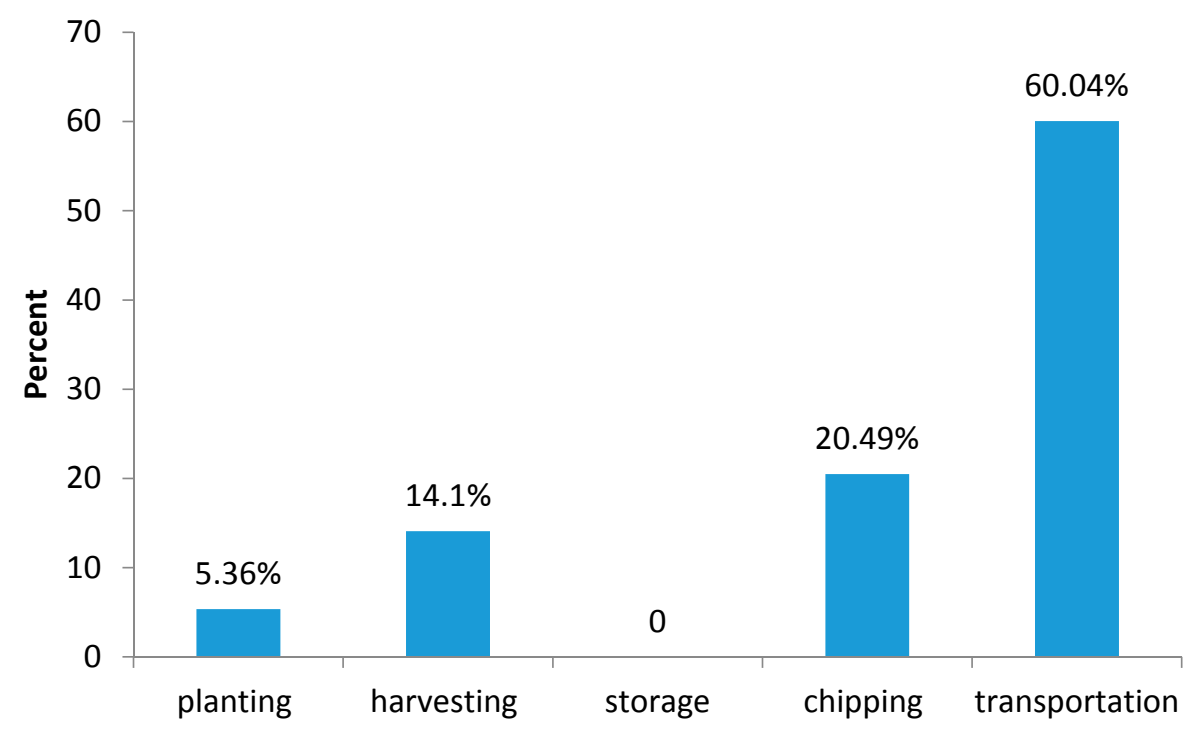

(a)

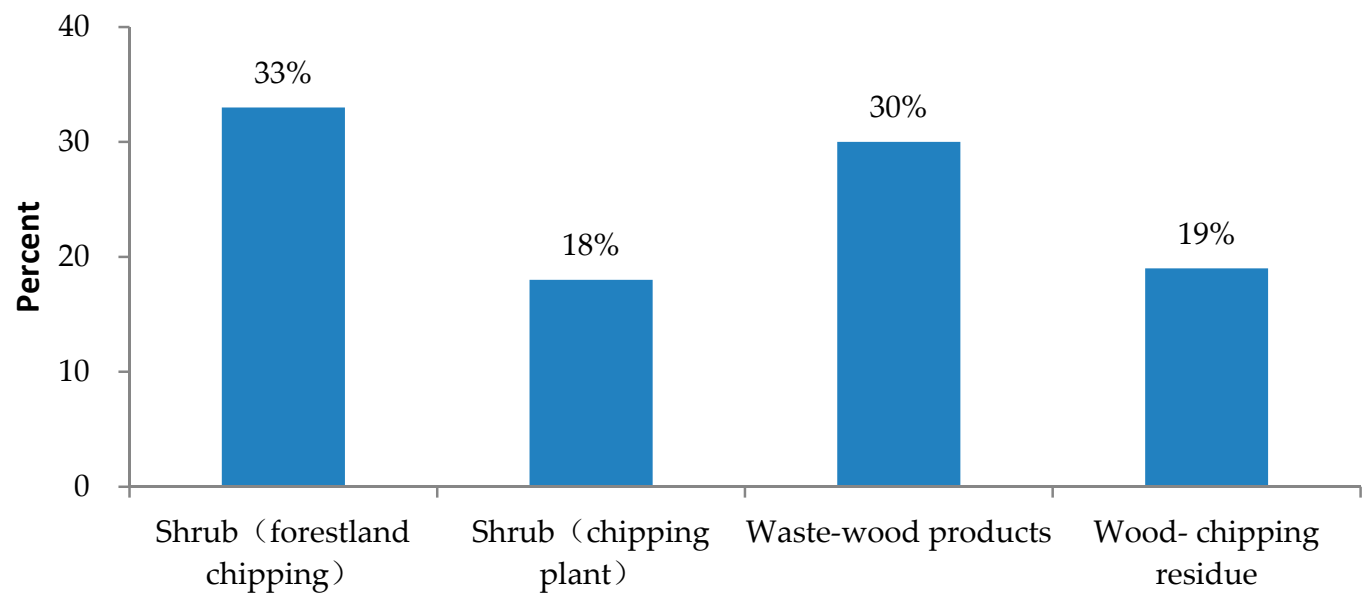

(b)

Figure 4. Percentage of the optimal $\mathrm{CO}_{2}$ emissions of each node (a) and three key raw materials (b).

Table 7. Sensitivity of the optimal solution to the transportation distance.

\begin{tabular}{cccc}
\hline Rate & Transportation Distance (km) & Supply Cost (Thousand \$) & $\mathbf{C O}_{\mathbf{2}}$ Emissions (Thousand kg) \\
\hline$-30 \%$ & 84.13 & 7333.7 & 5356.9 \\
$-20 \%$ & 95.77 & 7372.1 & 5463.9 \\
$-10 \%$ & 107.74 & 7411.5 & 5573.8 \\
$0 \%$ & 119.71 & 7450.9 & 5683.8 \\
$10 \%$ & 131.68 & 7490.4 & 5793.7 \\
$20 \%$ & 143.66 & 7529.8 & 5903.7 \\
$30 \%$ & 155.60 & 7569.2 & 6304.7 \\
\hline
\end{tabular}

Table 8. Sensitivity of the optimal solution to the unit chipping cost.

\begin{tabular}{cccc}
\hline Rate & Unit Chipping Cost (Thousand \$) & Supply Cost (Thousand \$) & $\mathbf{C O}_{\mathbf{2}}$ Emissions (Thousand kg) \\
\hline$-14.7 \%$ & 0.00872 & 7180.7 & 5729.2 \\
$-10 \%$ & 0.00920 & 7267.2 & 5712.2 \\
$0.0 \%$ & 0.01022 & 7450.9 & 5683.8 \\
$10 \%$ & 0.01124 & 7634.6 & 5692.8 \\
$14.7 \%$ & 0.01172 & 7721.2 & 5698.2 \\
\hline
\end{tabular}




\section{Discussion}

The major raw material for the company was sandy shrub stubble residue $(52.8 \%$ of all raw materials) and the biggest concern during the supply chain was high supply cost (50.3\% of the total supply cost). That supply cost was dependent largely on the raw material's own characteristics: (1) raw material in Inner Mongolia possessed the following characteristics: broad dispersion, low density, high moisture content [37,45]; (2) uneven seasonal availability [40]. The sandy shrub stubble residue could be transformed into bioenergy to promote the development of a residue-recycling economy. However, the unit cost of the sandy shrub stubble residue chipped in the forestland was $\$ 0.01394$ thousand less than that of the sandy shrub stubble residue chipped in the chipping plant after optimization. Although the chipping plant can achieve intensive chipping and improve efficiency, the construction of a chipping plant required heavy investment in terms of funds, equipment and labor. It was possible to increase the supply amount of chipped sandy shrub residue in the forestland ( $33 \%$ of the total supply), as shown in [32]. The price of a household shrub chipper was relatively high, so if the households have not specifically been engaged in raw material collection work, they would generally not be willing to buy a chipper which was why they would rather sell the non-chipped sandy shrub stubble residue to the chipping plant. On the other hand, the $\mathrm{CO}_{2}$ emissions of the sandy shrub stubble residue chipped in the chipping plant was 0.0002 thousand $\mathrm{kg}$ less than that of the sandy shrub stubble residue chipped in the forestland. The increased $\mathrm{CO}_{2}$ emissions of non-chipped residue during transportation were much smaller than the decrease in $\mathrm{CO}_{2}$ emissions in the chipping plant. Therefore, it is necessary to construct a chipping plant in an area that is rich in sandy shrub stubble residue.

The second raw material was the waste-wood products ( $25.69 \%$ of the total raw material) and it served the second-recycling use for bioenergy. Its supply should be decreased compared to the current situation because of its high acquisition cost. After optimization, the supply cost and the $\mathrm{CO}_{2}$ emissions were optimized, but the unit supply cost and the unit $\mathrm{CO}_{2}$ emissions were increased. The third raw material was the wood-chipping residue (22.22\%) and its optimal supply remained unchangeable compared to the current situation. Therefore, its supply cost and the $\mathrm{CO}_{2}$ emissions should be kept steady after optimization.

Not only did the enterprise optimize its supply chain, but it should also fulfil its social responsibility to lower $\mathrm{CO}_{2}$ emissions during the usage of forest biomass as much as possible. It was indicated that the transportation and chipping node had the greatest impact on the supply chain. The transportation node had the highest share of the total cost $(38.83 \%)$ and $\mathrm{CO}_{2}$ emissions $(60.04 \%)$. Similar to [45], the transportation to the terminal which served an important role in the woody biomass supply chain accounted for $23 \%$ and $31 \%$ of the total cost and total emissions, respectively. The unit transportation distance was significant regardless of road condition, particularly for low-density sandy shrub residue. This is mainly due to high fossil fuel consumption from the forestland to the terminal. In [46], the effect of unit transportation distance became evident when cumulated biomass and round wood were transported by the same trucks and over the same road and the impact of unit transportation distance on the cumulated biomass was larger than round wood. In this paper, all nodes of the supply chain were simultaneously economically and environmentally optimized with a reduction of $\$ 98.4$ thousand and 60.6 thousand $\mathrm{kg}$, respectively, to helpfully build a complete low-cost and low-carbon supply chain model. However, the $\mathrm{CO}_{2}$ emissions of the harvesting, skidding and transportation nodes were merely calculated in [38] which showed that chain-sawing, cableway skidding and truck transportation of raw material was the optimal mix to reduce emissions; this was echoed in [39] which analyzed the $\mathrm{CO}_{2}$ emissions of the woody biomass supply chain from the perspective of direct emissions and indirect emissions.

In the optimal model, the farmer's transportation distance was $119.71 \mathrm{~km}$, and the unit chipping cost was $\$ 0.0102$ thousand. After the sensitivity analysis, the farmer's transportation distance could be $84.13 \mathrm{~km}$ and the unit chipping cost could be $\$ 0.0102$ thousand, so the optimal solution remained unchangeable. For the farmer's transportation distance, the variation of supply cost and $\mathrm{CO}_{2}$ emissions correlated positively with the transportation distance; when the transportation distance decreased 
by $30 \%$, correspondingly the supply cost decreased by $1.5 \%$ and the $\mathrm{CO}_{2}$ decreased by $5.7 \%$. For the unit chipping cost, the variation of supply cost and $\mathrm{CO}_{2}$ emissions correlated negatively with the unit chipping cost; when the unit chipping cost decreased by $14.7 \%$, the supply cost decreased by $3.6 \%$ while the $\mathrm{CO}_{2}$ emissions increased by $0.8 \%$. A similar sensitivity analysis was conducted on the profitability of the biomass supply chain in [16] which examined the optimal solution to the variation in the demand and price of products, as well as the availability and the cost of forest residue. This paper differed from those aforementioned studies in that only the transportation distance and unit chipping cost were selected to conduct the sensitivity analysis based on the largest percentage of supply cost and $\mathrm{CO}_{2}$ emissions. Therefore, we may add other parameters into the sensitivity analysis to find out how the optimal results will change.

\section{Conclusions}

This study presented a multi-objective linear programming model and sensitivity analysis to optimize the supply chain of forest biomass power generation. The purpose was to investigate the trade-offs between economic and ecological benefits within the biomass supply chain of the Mao Wu Su biomass Thermoelectric Company. The optimal results show that the amount of sandy shrub residue should be increased and the amount of the waste-wood-products should be decreased; there is still a lot of room for optimization of the transportation path of sandy shrub residue; the cost and the $\mathrm{CO}_{2}$ emissions of transportation and chipping account for a large percentage of the overall supply chain. Finally, a sensitivity analysis was introduced to determine that the farmer's average transportation distance and the farmer's unit chipping cost are significant parameters in the transportation and chipping nodes. The findings on these two nodes for the Mao Wu Su biomass Thermoelectric Company are applicable to other companies with similar forest biomass supply chains.

In order to achieve a lower-cost supply chain and a $\mathrm{CO}_{2}$ emissions reduction, the following suggestions are put forward for the Mao Wu Su biomass Thermoelectric Company: (1) develop long-term cooperation with farmers to ensure a stable flow of sandy shrub residue for residue-recycling. The results show that the sandy shrub residue should be increased by 3750 thousand $\mathrm{kg}$. Farmers are of great importance for the supply of raw material for biomass production. Long-term cooperation with farmers will help to ensure a stable flow and increase the income and the enthusiasm of farmers to harvest the sandy shrub stubble and improve the quality of raw materials. Therefore, the enterprise could strengthen the importance of the farmer's participation in the forest biomass power industry through energy forest construction projects and by signing a long-term raw material supply contract with farmers and increasing subsidies for the main farmers; (2) buy chain-saws for regularly used farmers to improve efficiency. The farmers who are very much involved in the supply of sandy shrub stubble residue are generally over 55 years of age. Generally, they use a hoe to harvest shrub which is inefficient and laborious. On the other hand, most farming families are poor and generally cannot buy their own chain-saws. The price of a chain-saw is $\$ 0.188$ thousand. Farmers may find this price unaffordable, so borrowing from enterprises can help to improve efficiency; (3) build several chipping plants (middlemen) in areas that are rich in sandy shrub to shorten the required transportation distance and chipping cost. Based on the sensitivity analysis, the transportation distance of $87.13 \mathrm{~km}$ and chipping cost of $\$ 0.01022$ thousand are optimal parameters that should be established as soon as possible. The existing chipping equipment is limited in technology and popularity and a chipping plant (middlemen) needs to be introduced to reduce the cost of raw materials. Middlemen should be encouraged to participate in the forest biomass power supply chain and make full use of the role of the market mechanism, i.e., the price of raw material changes with the market to guarantee farmers' income. However, the construction of a chipping plant requires investment of a certain amount of capital so the number of middlemen should be considered carefully in the future.

Growth of the Mao Wu Su biomass Thermoelectric Company is contributing to the prevention of desertification and protection against the harsh ecosystem in semi-arid areas; it also motivates local farmers to plant much sandy shrub, thus promoting residue-resources recycling for bioenergy. 
In addition, the development of the enterprise helps to promote economic development and provides jobs for farmers. This case can set an example for other countries to follow, i.e., a bio-enterprise optimizes its supply chain for low-carbon development. The effective use of sandy shrub stubble residue will contribute towards the sustainable development of these regions, thus alleviating the energy crisis and future global warming. Future work should involve the addition of labor employment and the number of chipping plants (middleman) to the study, as well as analyzing the amount of subsidies provided and how these subsidies can support the forest biomass power generation industry.

Acknowledgments: Financial support for this research was provided by the Project of Humanity and Social Science Youth Foundation of Education Ministry of China (Grant No.13YJCZH131) and the Project of the General Program of National Social Science Foundation of China (Grant No. 15BGL130).

Author Contributions: Min Zhang and Feng Mi conducted the background research, built the entire framework of the article and edited the content. Guangyu Wang provided additional guidance and suggestions. Min Zhang, Yi Gao and Zhenqi Wang gathered the statistical data and calculated the results of the article. All authors have read and approved the final manuscript.

Conflicts of Interest: The authors declare no conflict of interest.

\section{Appendix A}

\begin{tabular}{|c|c|}
\hline Name & Explanation \\
\hline$M_{i}$ & $\begin{array}{l}\text { Raw material type } \\
i \in\{\text { sandy shrub stubble residue, wood - chipping residue and waste }- \text { wood products }\}\end{array}$ \\
\hline$K_{k}$ & Raw material transportation form $k \in\{$ chipped, nochipped $\}$ \\
\hline$T_{j}$ & $\begin{array}{l}\text { Transportation path, } \\
\begin{aligned} j \in\{\text { forestland } & \text {-skidding area, skidding point - storage point, storage point } \\
& \text { - chipping plant, chipping plant - power plant, forestland } \\
& \text { - storage point, forestland - chipping plant, forestland } \\
& \text { - power plant, storage point - power plant, storage point } \\
& \text { - power plant, skidding point - chipping plant }\}\end{aligned}\end{array}$ \\
\hline$U_{u}$ & $\begin{array}{l}\text { Planting equipment, } \\
u \in\{\text { no, land preparation machine, tap machine, weeding machine }\}\end{array}$ \\
\hline$V_{v}$ & $\begin{array}{l}\text { Harvesting equipment } \\
v \in\{\text { no, small hand }- \text { held harvesters, medium }- \text { sized harvester }\}\end{array}$ \\
\hline$W_{w}$ & $\begin{array}{l}\text { Skidding equipment, } \\
w \in\{\text { no, handcart, gathering manchine, firewood collecting machine, tractor }\}\end{array}$ \\
\hline$X_{x}$ & Chipping equipment, $x \in\{$ no, chipping machine, crusher, chopper $\}$ \\
\hline$Y_{y}$ & $\begin{array}{l}\text { Transportation equipment, } \\
y \in\{\text { human }- \text { load, agricultural tricycles, truck }\}\end{array}$ \\
\hline$D_{d}$ & Skidding point, $d \in\{$ no, forest - road, roadside, chipping plant $\}$ \\
\hline$D_{s}$ & Storage point, $s \in\{$ no, site 1 , site $2, \ldots$, site $n\}, n \in Z$ \\
\hline$D_{c}$ & Chipping point, $c \in\{$ no, site 1 , site $2, \ldots$, site $m\}, m \in Z$ \\
\hline
\end{tabular}

\section{References}

1. Lim, C.H.; Lam, H.L. Biomass supply chain optimisation via novel Biomass Element Life Cycle Analysis (BELCA). Appl. Energy 2016, 161, 733-745. [CrossRef]

2. Srirangan, K.; Akawi, L.; Moo-Young, M.; Chou, C.P. Towards sustainable production of clean energy carriers from biomass resources. Appl. Energy 2012, 100, 172-186. [CrossRef]

3. Lee, K.; Oh, W. Analysis of $\mathrm{CO}_{2}$ emissions in APEC countries: A time-series and a cross-sectional decomposition using the log mean Divisia method. Energy Policy 2006, 34, 2779-2787. [CrossRef] 
4. National Development and Reform Commission (NDRC). National Climate Change Plan for 2014-2020. 2011. Available online: http:/ /www.sdpc.gov.cn/zcfb/zcfbtz/201201/t20120113_456506.html (accessed on 12 September 2017).

5. Vinuya, F.; DiFurio, F.; Sandoval, E. A decomposition analysis of $\mathrm{CO}_{2}$ emissions in the United States. Appl. Econ. Lett. 2010, 17, 925-931. [CrossRef]

6. China-nengyuan.com. Biomass Energy Development in 13th Five-Year Plan. 2016. Available online: http:/ / www.china-nengyuan.com/news/101873.html (accessed on 12 September 2017).

7. Zhang, L.; Zhang, C.H. Review of research on forest biomass energy development. Econ. Issues 2012, 10, 186-190. (In Chinese)

8. Karjalainen, T.; Asikainen, A.; Ilavsky, J.; Zamboni, R.; Hotari, K.E.; Röser, D. Estimation of Energy Wood Potential in Europe; The Finnish Forest Research Institute: Vantaa, Finland, 2004; pp. 1-43.

9. Smeets, E.M.W.; Faaij, A.P.C. Bioenergy potentials from forestry in 2050. Clim. Chang. 2006, 81, 353-390. [CrossRef]

10. Zhang, C.H.; Zhang, L. Low-Carbon Economy and Forest Biomass Energy Development; China Forestry Press: Beijing, China, 2015; pp. 189-196. ISBN 978-750-387-929-6. (In Chinese)

11. Allen, J.; Browne, M.; Hunter, A.; Boyd, J.; Palmer, H. Logistics management and costs of biomass fuel supply. Int. J. Phys. Distrib. Logist. Manag. 1998, 28, 463-477. [CrossRef]

12. Development Status of Biomass Power Generation at Home and Abroad. 2015. Available online: https: / / wenku.baidu.com/view/3aef6db1ad02de80d5d84083 (accessed on 12 September 2017).

13. Ranking Report on China's Biomass Power Generation Enterprises in 2016. 2016. Available online: http: / / huanbao.bjx.com.cn/news/20170713/836917-2.shtml (accessed on 12 September 2017). (In Chinese)

14. United Nations News. The Ecological Project of the Mao Wu Su Biomass Thermoelectric Company in Inner Mongolia, China Introduced Successful Experience in the United Nations. 2012. Available online: http:/ / www.un.org/chinese/News/story.asp?NewsID=17465 (accessed on 12 September 2017).

15. Shabani, N.; Akhtari, S.; Sowlati, T. Value chain optimization of forest biomass for bioenergy production: A review. Renew. Sustain. Energy Rev. 2013, 23, 299-311. [CrossRef]

16. Cambero, C.; Sowlati, T.; Marinescu, M.; Röser, D. Strategic optimization of forest residue to bioenergy and biofuel supply chain. Int. J. Energy Res. 2015, 39, 439-452. [CrossRef]

17. Klein, D.; Wolf, C.; Schulz, C.; Weber-Blaschke, G. Environmental impacts of various biomass supply chains for the provision of raw wood in Bavaria, Germany, with focus on climate change. Sci. Total Environ. 2016, 539, 45-60. [CrossRef] [PubMed]

18. Roberts, D.G. Convergence of the fuel, food and fibre markets: A forest sector perspective. Int. For. Rev. 2008, 10, 81-94. [CrossRef]

19. Trømborg, E.; Solberg, B. Forest sector impacts of the increased use of wood in energy production in Norway. For. Policy Econ. 2010, 12, 39-47. [CrossRef]

20. Bolkesjo, T.F.; Tromborg, E.; Solberg, B. Bioenergy from the forest sector: Economic potential and interactions with timber and forest products markets in Norway. Scand. J. For. Res. 2006, 21, 175-185. [CrossRef]

21. Raunikar, R.; Buongiorno, J.; Turner, J.A.; Zhu, S. Global outlook for wood and forests with the bioenergy demand implied by scenarios of the Intergovernmental Panel on Climate Change. For. Policy Econ. 2010, 12, 48-56. [CrossRef]

22. Sjølie, H.K.; Trømborg, E.; Solberg, B.; Bolkesjø, T.F. Effects and costs of policies to increase bioenergy use and reduce GHG emissions from heating in Norway. For. Policy Econ. 2010, 12, 57-66. [CrossRef]

23. Schwarzbauer, P.; Stern, T. Energy vs. material: Economic impacts of a "wood-for-energy scenario" on the forest-based sector in Austria-A simulation approach. For. Policy Econ. 2010, 12, 31-38. [CrossRef]

24. Bürger, V.; Klinski, S.; Lehr, U.; Leprich, U.; Nast, M.; Ragwitz, M. Policies to support renewable energies in the heat market. Energy Policy 2008, 36, 3150-3159. [CrossRef]

25. Zhang, Y. The Policy Research on Renewable Energy Price in the Inner Mongolia. Master's Thesis, Inner Mongolia University, Hohhot City, China, 2015. (In Chinese)

26. Xie, L.L. Analysis on Supporting Policy of Forestry Biomass Energy Industry in China. Master's Thesis, Beijing Forestry University, Beijing, China, 2014. (In Chinese)

27. Sun, F.L.; Wang, Z.Y.; Ye, H. Development Status, Possible Impacts and Countermeasures of Forest biomass Industry. Econ. Issues 2012, 3, 149-153. (In Chinese) 
28. Dong, F.X. Study on the Development of Wood Biomass Energy in China Based on Regional Forest Resources. Master's Thesis, Beijing Forestry University, Beijing, China, 2014. (In Chinese)

29. Oberscheider, M.; Zazgornik, J.; Henriksen, C.B.; Gronalt, M.; Hirsch, P. Minimizing driving times and greenhouse gas emissions in timber transport with a near-exact solution approach. Scand. J. For. Res. 2013, 28, 493-506. [CrossRef]

30. Whalley, S.; Klein, S.J.W.; Benjamin, J. Economic analysis of woody biomass supply chain in Maine. Biomass Bioenergy 2017, 96, 38-49. [CrossRef]

31. Yoshioka, T.; Aruga, K.; Nitami, T.; Sakai, H.; Kobayashi, H. A case study on the costs and the fuel consumption of harvesting, transporting, and chipping chains for logging residue in Japan. Biomass Bioenergy 2006, 30, 342-348. [CrossRef]

32. Gunnarsson, H.; Rönnqvist, M.; Lundgren, J.T. Supply chain modelling of forest fuel. Eur. J. Oper. Res. 2004, 158, 103-123. [CrossRef]

33. Rentizelas, A.A.; Tolis, A.J.; Tatsiopoulos, I.P. Logistics issues of biomass: The storage problem and the multi-biomass supply chain. Renew. Sustain. Energy Rev. 2009, 13, 887-894. [CrossRef]

34. Emer, B.; Grigolato, S.; Lubello, D.; Cavalli, R. Comparison of biomass feedstock supply and demand in Northeast Italy. Biomass Bioenergy 2011, 35, 3309-3317. [CrossRef]

35. Serengil, Y.; Pamukçu, P. Managing Forests as Complex Adaptive Systems-Building Resilience to the Challenge of Global Change. Int. J. Environ. Stud. 2013, 71, 117-119. [CrossRef]

36. Shabani, N.; Sowlati, T. A mixed integer non-linear programming model for tactical value chain optimization of a wood biomass power plant. Appl. Energy 2013, 104, 353-361. [CrossRef]

37. Zhou, Y.; Xu, S.Y.; Qian, X.H.; Han, Z.Z.; Wang, K.F. Study on multi-objective optimization model of bio-energy production. Comput. Appl. Chem. 2007, 24, 1501-1504. (In Chinese)

38. Zhou, Y.; Li, D.; Wu, Z.L.; Zhou, C.J.; Zheng, L.F. Study on carbon emissions in the forest transporting operation. For. Eng. 2014, 30, 1-5. (In Chinese)

39. Zheng, W.W.; Zhang, L.Y.; Qiu, R.Z. Study on Carbon Emissions from Woody Biomass Raw Material Supply Chain in Fujian Province. J. Southwest For. Univ. 2015, 35, 77-82. (In Chinese)

40. Zheng, W.W. The Optimization of Raw Material for Wood-Biomass Energy Plant Supply Chain Based on the LCA. Master's Thesis, Fujian Agriculture and Forestry University, Fuzhou, China, 2016. (In Chinese)

41. Zhang, D.H.; Mi, F.; Wu, W.H. Technical Economics; China Forestry Press: Beijing, China, 2012; pp. $123-156$. ISBN 978-750-386-800-9. (In Chinese)

42. National Bureau of Statistics of the People's Republic of China. China Statistical Yearbook 2016. 2016. Available online: http:/ / www.stats.gov.cn/tjsj/ndsj/2016/indexch.htm (accessed on 12 September 2017).

43. National Bureau of Statistics of the People's Republic of China. China Energy Statistical Yearbook 2014. 2015. Available online: http://www.stats.gov.cn/tjsj./tjcbw/201512/t20151210_1287828.html (accessed on 12 September 2017).

44. China's Forestry. Inner Mongolia Autonomous Region Forestry Department Website News. 2015. Available online: http:/ /www.nmglyt.gov.cn/cyc/cyxx/1tqy/201508/t20150824_113300.html (accessed on 12 September 2017).

45. Valente, C.; Hillring, B.G.; Solberg, B. Bioenergy from mountain forest: A life cycle assessment of the Norwegian woody biomass supply chain. Scand. J. For. Res. 2011, 26, 429-436. [CrossRef]

46. Blouin, M.; Cormier, D. Carbon and Greenhouse Gas Accounting of Forest Operations in FPInterface. Int. J. For. Eng. 2012, 23, 64-69. [CrossRef]

(C) 2017 by the authors. Licensee MDPI, Basel, Switzerland. This article is an open access article distributed under the terms and conditions of the Creative Commons Attribution (CC BY) license (http://creativecommons.org/licenses/by/4.0/). 